\title{
BACTERIOLOGICAL STUDY OF PYODERMAS IN A TERTIARY CARE CENTRE
}

\author{
B. V. N. Sravani', B. Suresh Kumar², V. V. Nag Rajneesh Mavuri'3, V. Sri Lakshmi', B. Balachandrudu5, G. M. V. Padmaja6, \\ J. Rupa Ramani7, N. Suneetha Rani Patro ${ }^{8}$
}

${ }_{1}^{1}$ Postgraduate Student, Department of Pathology, Deccan Medical College.

${ }^{2}$ Associate Professor, Department of DVL, Andhra Medical College.

${ }^{3}$ Postgraduate Student, Department of DVL, Andhra Medical College.

${ }^{4}$ Postgraduate Student, Department of DVL, Andhra Medical College.

5 Professor and HOD, Department of DVL, Andhra Medical College.

${ }^{6}$ Postgraduate Student, Department of DVL, Andhra Medical College.

${ }^{7}$ Postgraduate Student, Department of DVL, Andhra Medical College.

${ }^{8}$ Postgraduate Student, Department of DVL, Andhra Medical College.

\begin{tabular}{l}
\hline ABSTRACT \\
BACKGROUND \\
Bacterial skin infection especially pyoderma, commonly caused by Staphylococcus aureus and group A Streptococci, is quite common \\
in Indian dermatology clinics. Despite a number of new antibiotics, the incidence of bacterial resistance is rising. Our aim is to find \\
out causative organisms and their latest antibiotic susceptibility patterns in pyodermas.
\end{tabular}

\section{MATERIALS AND METHODS}

All outpatients and inpatients admitted in the Dermatology wards in King George Hospital, Visakhapatnam, Andhra Pradesh were screened over 12 months and those with erosive skin lesions and/or purulent discharge were included in the study and swabs were sent for culture and sensitivity.

\section{RESULTS}

Majority of cases 38/50 (76\%) comprised of secondary pyodermas while primary pyodermas constituted only $12 / 50$ cases (24\%). Single organism was isolated in 40 cases (80\%). More than one type of organism was isolated in 2 cases (4\%) while none could be isolated from $8(16 \%)$ cases. Staphylococcus aureus spp. was the commonest organism isolated in $30(60 \%)$ cases and out of these, coagulase positive strains were found to be highly susceptible to amikacin (20 cases-100\%). Coagulase negative strains were sensitive to amikacin (6 cases-60\%) and gentamycin ( 4 cases- $40 \%$ ) respectively.

\section{CONCLUSION}

This study gives an indication of the present pattern of bacteriological profile of pyodermas in a tertiary care hospital. In-vitro testing is essential as knowledge of the causative organisms and resistance patterns can help us select appropriate antibiotics without wasting time in using resistant drugs.

\section{KEYWORDS}

Bacteriological Profile, Pyodermas, Antibiotic Sensitivity.

HOW TO CITE THIS ARTICLE: Sravani BVN, Kumar BS, Mavuri VVNR, et al. Bacteriological study of pyodermas in a tertiary care centre. J. Evolution Med. Dent. Sci. 2017;6(31):2563-2566, DOI: 10.14260/Jemds/2017/554

\section{BACKGROUND}

Pyoderma means any skin disease that is pyogenic (has pus). Pyoderma may be primary or secondary and superficial or deep. Primary pyoderma, includes superficial bacterial infections such as Impetigo, ecthyma, folliculitis, furuncle, carbuncle, abscess, etc.

Secondary pyoderma is primarily caused by conditions that involve bacterial infections below the epidermal layer of skin

Financial or Other, Competing Interest: None.

Submission 09-03-2017, Peer Review 03-04-2017,

Acceptance 08-04-2017, Published 17-04-2017.

Corresponding Author:

Dr. B. V. N. Sravani,

Postgraduate Student,

Department of Pathology, Deccan Medical College,

C/o. Department of Dermatology, Venereology \& Leprology,

Andhra Medical College,

Visakhapatnam,

Andhra Pradesh, India.

E-mail: drsrilakshmi99@gmail.com

DOI: $10.14260 /$ jemds $/ 2017 / 554$

\section{(c) (1) $(9)$}

Some conditions that contribute to the secondary pyodermas are ectoparasite infestations, fungal infections, atopic or contact type allergic responses, a weakened immune system as a result of poor nutrition or prolonged steroid use, cancer, or endocrine diseases like diabetes, hypothyroidism.

Pyodermas are quite common in India and constitute a major portion of the cases in Dermatology clinics. Many cases these days do not respond to the antibiotics that were previously very effective in such cases. Perhaps, indiscriminate use of topical and systemic antibiotics has contributed to this situation. ${ }^{[1-4]}$ The emergence of antibiotic resistance has significantly eroded the utility of established antibiotics and poses a serious threat to public health worldwide. In order to successfully treat cases of pyodermas, detailed knowledge is necessary regarding the various causative organisms and their sensitivity patterns. Considering these aspects, the present study was an attempt to find out the causative organisms and their antibiotic susceptibility patterns in different cases of primary and secondary pyodermas who attended to the Dermatology Department in a tertiary care hospital. 


\section{MATERIALS AND METHODS}

All patients who attended to Dermatology Department of King George Hospital, Visakhapatnam from August 2015 to August 2016 were screened for pyogenic skin infections of both primary and secondary types. Only those who had erosive skin lesions with exudative or purulent discharge were included in the study. Fifty patients of various ages and both sexes were identified for inclusion in the study; these included patients from urban as well as rural backgrounds. Sterile swabs were used to aseptically collect exudate or pus from the lesions. Care was taken that these samples were collected before the start of antibiotic therapy. The swabs were transported immediately to the microbiology laboratory for culture and sensitivity examination.

\section{RESULTS}

The demographic characteristics of the patients enrolled in the study are shown in Table 1. Primary bacterial skin infections (primary pyoderma) accounted for $12(24 \%)$ cases while 38 (76\%) cases were of secondary pyoderma. Among the primary pyodermas, impetigo was the commonest entity seen (nine cases-18\%); among the secondary pyodermas, secondarily infected pemphigus vulgaris was the commonest, being seen in 22 cases (44\%) [Table 2].

A single infecting organism was isolated from $40(80 \%)$ cases, more than one type of organism from two cases (4\%) and no organism from eight cases (14.75\%). Coagulase positive methicillin-sensitive (MS) Staphylococcus was isolated from 14 (28\%) cases, coagulase positive methicillin resistant (MR) Staphylococcus in six (12\%) cases, coagulase negative MS Staphylococcus in nine $(18 \%)$ cases, coagulase negative MR Staphylococcus in one (2\%) case. Thus, overall there were $30(60 \%)$ cases of Staphylococcus spp., which included seven (14\%) cases of methicillin resistant Staphylococcus aureus (MRSA). Out of these 30 cases, coagulase positive Staphylococcus accounted for 20 (40\%) cases and coagulase negative Staphylococcus accounted for 10 cases $(20 \%)$. The second most common organism isolated was Klebsiella Spp. (six, 12\%), Streptococcus, Enterococcus and E. coli + Enterococcus were isolated in two patients (4\%) each [Table 3].

Among the S. aureus strains, susceptibility to antibiotics was as follows: amikacin- (26 cases), gentamycin-( 9 cases), ciprofloxacin-(10 cases) and gatifloxacin (15 cases) [Table 4].

\begin{tabular}{|c|c|}
\hline Age in Years & n (\%) \\
\hline $0-10$ & $6(12 \%)$ \\
\hline $11-20$ & $7(14 \%)$ \\
\hline $21-30$ & $8(16 \%)$ \\
\hline $31-40$ & $15(30 \%)$ \\
\hline $41-50$ & $4(8 \%)$ \\
\hline $51-60$ & $5(10 \%)$ \\
\hline$>60$ & $5(10 \%)$ \\
\hline Gender & $27(54 \%)$ \\
\hline male & $23(46 \%)$ \\
\hline female & $32(64 \%)$ \\
\hline Rural vs. Urban & $18(36 \%)$ \\
\hline Rural & \\
\hline Urban & Table 1. Demographic Characteristics \\
of the Study Cases (n=50)
\end{tabular}

\begin{tabular}{|c|c|c|c|}
\hline $\begin{array}{c}\text { Primary } \\
\text { Pyodermas }\end{array}$ & $\mathbf{n}$ & $\begin{array}{l}\text { Secondary } \\
\text { Pyodermas }\end{array}$ & $\mathbf{n}$ \\
\hline Impetigo & $9(18 \%)$ & $\begin{array}{l}\text { Infective } \\
\text { Pemphigus }\end{array}$ & $22(44 \%)$ \\
\hline Folliculitis & $2(4 \%)$ & Infective SJS & $8(16 \%)$ \\
\hline \multirow[t]{3}{*}{ Carbuncle } & $1(2 \%)$ & $\begin{array}{l}\text { Infective Exfoliative } \\
\text { dermatitis }\end{array}$ & $4(8 \%)$ \\
\hline & & Infective Scabies & $3(6 \%)$ \\
\hline & & $\begin{array}{c}\text { Infective Atopic } \\
\text { dermatitis }\end{array}$ & $1(2 \%)$ \\
\hline Total & $12(24 \%)$ & & $38(76 \%)$ \\
\hline \multicolumn{4}{|c|}{$\begin{array}{c}\text { Table 2. Distribution of Cases of Primary and Secondary } \\
\text { Pyoderma }\end{array}$} \\
\hline
\end{tabular}

\begin{tabular}{|c|c|c|c|c|c|c|c|c|}
\hline 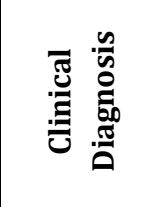 & $z$ & 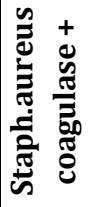 & 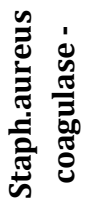 & $\begin{array}{l}\frac{\pi}{0} \\
\frac{0}{5} \\
\frac{0}{2} \\
\frac{0}{2}\end{array}$ & 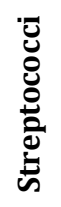 & 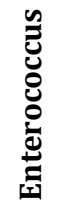 & 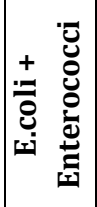 & $\begin{array}{l}5 \\
\vdots \\
0 \\
0 \\
0 \\
0 \\
z \\
z\end{array}$ \\
\hline Impetigo & 9 & 2 & 2 & - & 1 & - & - & 4 \\
\hline Folliculitis & 2 & 1 & - & - & - & - & - & 1 \\
\hline Carbuncle & 1 & - & 1 & - & - & - & - & - \\
\hline Total & 12 & 3 & 3 & - & 1 & - & - & 5 \\
\hline \begin{tabular}{|c|} 
Infected \\
Pemphigus
\end{tabular} & 22 & 11 & 4 & 4 & - & 1 & 1 & 1 \\
\hline Infected SJS & 8 & 3 & 2 & 2 & - & - & - & - \\
\hline $\begin{array}{c}\text { Infected } \\
\text { Exfoliative } \\
\text { dermatitis }\end{array}$ & 4 & 1 & 1 & - & - & 1 & 1 & - \\
\hline $\begin{array}{c}\text { Infected } \\
\text { Scabies }\end{array}$ & 3 & 1 & - & - & 1 & - & - & 1 \\
\hline $\begin{array}{c}\text { Infected } \\
\text { Atopic } \\
\text { dermatitis }\end{array}$ & 1 & 1 & - & - & - & - & - & - \\
\hline Total & 38 & 17 & 7 & 6 & 1 & 2 & 2 & 8 \\
\hline $\begin{array}{c}\text { Grand } \\
\text { Total }\end{array}$ & 50 & & & & & & & \\
\hline Table & & ${ }^{\mathrm{r}} \mathrm{Co}$ & sof & , yu & as & & from & \\
\hline
\end{tabular}

\begin{tabular}{|c|c|c|c|c|c|c|}
\hline 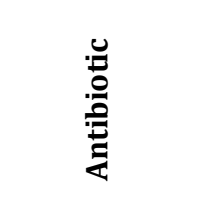 & 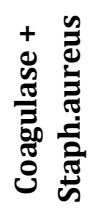 & 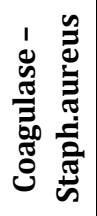 & 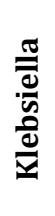 & 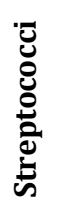 & 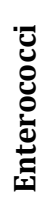 & 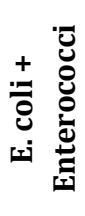 \\
\hline Ampicillin & 12 & 2 & - & 2 & - & - \\
\hline Cephalexin & 14 & - & 4 & 2 & - & - \\
\hline Azithromycin & 12 & 4 & 1 & 2 & - & - \\
\hline Amikacin & 20 & 6 & 2 & 1 & - & - \\
\hline Gentamycin & 5 & 4 & 4 & 1 & - & 1 \\
\hline Ciprofloxacin & 10 & - & 4 & 2 & 1 & 2 \\
\hline Gatifloxacin & 13 & 2 & 3 & 1 & 1 & - \\
\hline \multicolumn{7}{|c|}{$\begin{array}{l}\text { Table 4. Antibiotics Susceptibility and Resistance } \\
\text { Pattern of Organisms Isolated }\end{array}$} \\
\hline
\end{tabular}




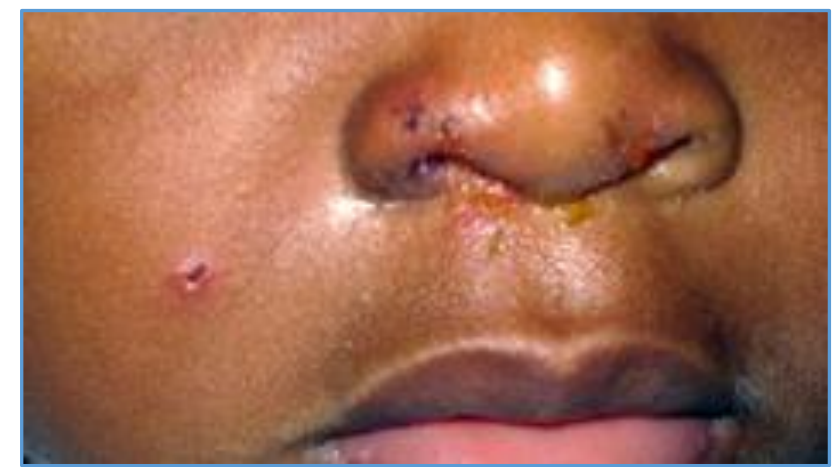

Figure 1. Impetigo

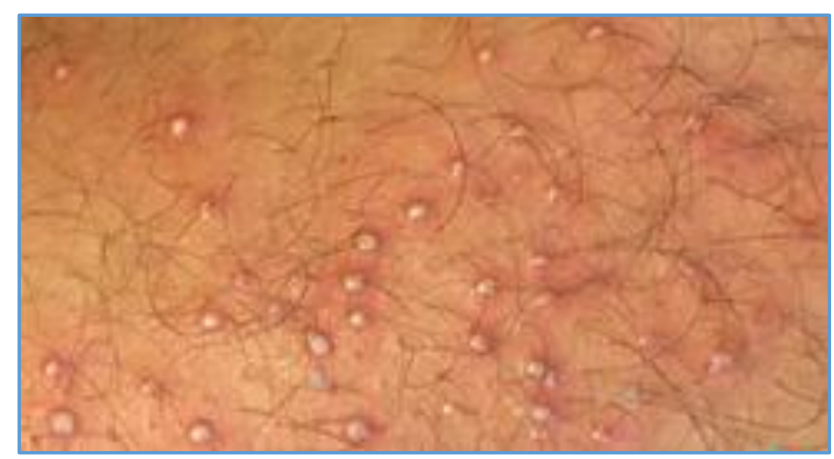

Figure 2. Folliculitis

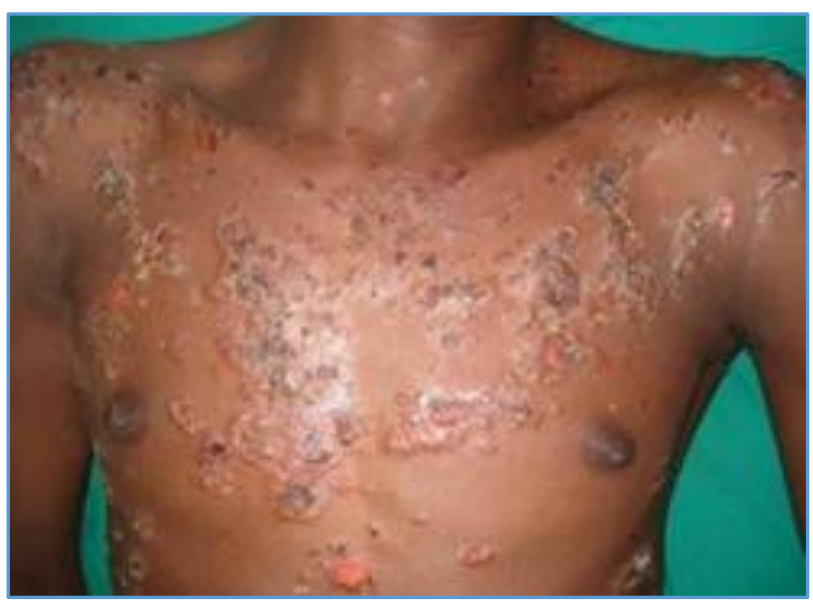

Figure 3. Pemphigus Vulgaris with Secondary Infection

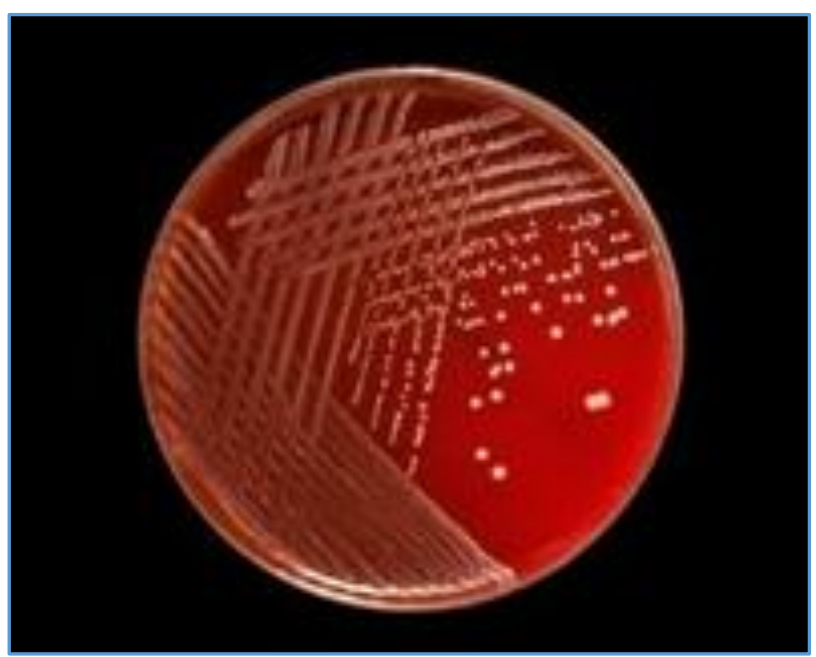

Figure 4. Colonies of Staphylococci

\section{DISCUSSION}

In all, we had 50 cases of pyoderma in this study. There were $12(24 \%)$ cases of primary pyoderma, of which 9 cases were of impetigo. Impetigo formed the largest group followed by folliculitis and carbuncle. Similar high incidence of impetigo has been reported by others.[1,5] Males were affected more than females in this study, as has also been reported by others. [4,6-9] Among the secondary pyodermas, infected pemphigus vulgaris was the commonest diagnosis, followed by Stevens-Johnson syndrome (SJS). Infected pemphigus (vulgaris + foliaceus), with a total of 22 cases (44\%) was the commonest diagnosis among all cases of pyoderma; second commonest diagnosis was impetigo- nine cases $(18 \%)$ and this was followed by SJS (eight cases-16\%). In bacteriological analysis, we observed that Staphylococcus spp. (30 cases$60 \%$ ) were the most common organisms to be isolated; this included MRSA- which was isolated in seven cases (14\%). A similar high incidence of MRSA has been reported in other studies.[2,3,6,8,10] Among the Staphylococcal strains isolated, 20 $(40 \%)$ were coagulase positive and $10(20 \%)$ were coagulase negative.

A high incidence of coagulase positive Staphylococcus in pyoderma has been reported by several workers. [2-4] Coagulase negative strains have also been reported to be aetiological agents. ${ }^{[3,11]}$ S. aureus and Streptococci are considered to be the main aetiological agents of cutaneous bacterial infections [12] and these have been isolated in different proportions of cases in studies in India and abroad. [2,6,7,9,10,13,14] The other organisms isolated in this study were Klebsiella in six (12\%) patients, Streptococcus, Enterococcus and E. coli + Enterococci in two patients each (4\%). Culture results were negative in eight patients (16\%), which is similar to the studies by Baslas et al (negative culture results in 14.9\%) and Rahul et al (negative culture results in 16.3\%).[8,15]

The antibiotic susceptibility patterns of the various isolates is shown in Table 4. In this study, most of coagulase positive strains of Staphylococcus were susceptible to amikacin (20 cases-100\%), gentamycin (5 cases-25\%) and ciprofloxacin (10 cases-50\%). Coagulase negative Staphylococci were largely susceptible to amikacin (six cases$60 \%$ ) and gentamycin (four cases-40\%) but showed relatively low susceptibility to ampicillin (two cases 20\%), azithromycin (four cases-40\%) and gatifloxacin (two cases-20\%). Klebsiella was sensitive to amikacin (two cases-33.3\%), gentamycin (four cases-66.66\%), ciprofloxacin (four cases-66.6\%), and gatifloxacin (three cases-50\%). Most of the strains were found to be resistant to one or more antibiotics. $[2,3,6,8,11]$

Most of the coagulase positive Staphylococcus strains were resistant to azithromycin and ampicillin (eight cases-40\%), gatifloxacin (seven cases each-35\%), and cephalexin (eight cases-40\%). Klebsiella spp. were resistant to ciprofloxacin, and cephalexin [two cases (33.33\%) each]. Streptococci were sensitive to ampicillin, azithromycin, cephalexin, ciprofloxacin in two cases $(100 \%)$ each while sensitivity to gentamycin, gatifloxacin and amikacin was seen in one case (50\%) each. Most of organisms were highly sensitive to the newer antibiotics while showing low susceptibility or resistance to the conventional antibiotics. $[2,8,10,14,16]$ 


\section{CONCLUSION}

This study gives an indication of present pattern of bacterial infections in pyodermas. Multidrug resistance has become a clinical challenge. Most of the bacterial strains were found to be resistant to one or more antibiotics. With knowledge of the likely causative organisms and their resistance patterns, the most suitable antibiotic therapy can be started without waiting for antibiogram results, and thus help avoid unnecessary medication with ineffective drugs.

\section{REFERENCES}

[1] Verma KC, Chug TD, Bhatia KK. Streptococci in pyoderma. Indian J Dermatol Venereol Leprol 1981;47(4):202-7.

[2] Mathews MS, Garg BR, Kanungo R. A clinicobacteriological study of primary pyodermas in children in Pondicherry. Indian J Dermatol Venereol and Leprol 1992;58(3):183-7.

[3] Ramani TV, Jaykar PA. Bacteriological study of 100 cases of pyodermas with special reference to staphylococci, their antibiotic sensitivity and phage pattern. Indian J Dermatol Venereol Leprol 1980;46(5):282-6.

[4] Khare AK. A clinical and bacteriological study of pyodermas. Indian J Dermatol Venereol Leprol 1988;54(4):192-5.

[5] Ghadage DP, Sali YA. Bacteriological study of pyoderma with special reference to antibiotic susceptibility to newer antibiotics. Indian J Dermatol Venereol Leprol 1999;65(4):177-81.

[6] Sachdev D, Amladi S, Natraj G, et al. An outbreak of methicillin-resistant staphylococcus aureus (MRSA) infection in dermatology indoor patients. Indian J Dermatol Venereol Leprol 2003;69(6):377-80.
[7] Kandhari KC, Omprakash, Singh G. Bacteriology of pyodermas. Indian J Dermatol Venereol 1962;28:125.

[8] Patil R, Baveja S, Nataraj G, et al. Prevalence of methicillin-resistant staphylococcus aureus (MRSA) in community-acquired primary pyoderma. Indian J Dermatol Venereol 2006;72(2):126-8.

[9] Tan HH, Tay YK, Goh CL. Bacterial skin infections at a tertiary dermatological centre. Singapore Med J 1998;39(8):353-6.

[10] Chopra A, Puri R, Mittal RR, et al. A clinical and bacteriological study of pyodermas. Indian J Dermatol Venerol Leprol 1994;60:200-2.

[11] Bhaskaran CS, Rao PS, Krishnamurty T, et al. Bacteriological study of pyoderma. Indian J Dermatol Venereol Leprol 1979;45(3):162-70.

[12] Collee JG, Fraser AG, Marmion BP, et al. Practical medical microbiology. 14th edn. Philadelphia: Churchill Livingstone. Mackie and McCartney 1996:P 131.

[13] Asati DP, Sharma VK, Khandpur S, et al. Clinical and bacteriological profile and outcome of sepsis in dermatology ward in tertiary care centre in New Delhi. Indian J Dermatol Venereol Leprol 2011;77(2):141-7.

[14] Pasricha A, Bhujwala RA, Shriniwas. Bacteriological study of pyoderma. Indian J Path Bact 1972;15(4):1318.

[15] Baslas RG, Arora SK, Mukhija RD, et al. Organisms causing pyoderma and their susceptibility patterns. Indian J Dermatol Venereol Leprol 1990;56:127-9.

[16] Kar PK, Sharma NP, Shah BH. Bacteriological study of pyoderma in children. Indian J Dermatol Venereol Leprol 1985;51:325-7. 